\title{
ИССЛЕДОВАНИЕ АНТИОКСИДАНТНЫХ СВОЙСТВ НОВЫХ СИНТЕЗИРОВАННЫХ ПОЛИФЕНОЛЬНЫХ ПРОИЗВОДНЫХ 2Н-ИМИДАЗОЛОВ
}

\author{
Е.Р. Газизуллина ${ }^{1}$, Е.Л. Герасимова', Т.Д. Мосеев ${ }^{1}$, М.В. Борисова', \\ Е.А. Никифоров', М.В. Вараксин ${ }^{1,2}$, А.В. Иванова', О.Н. Чупахин ${ }^{1,2}$, \\ B.Н. Чарушин ${ }^{1,2}$
}

1Уральский федеральный университет, 620002, Россия, Екатеринбург, ул. Мира, 19.

${ }^{2}$ Институт органического синтеза им. И.Я. Постовского УрО РАН, 620990, Россия, Екатеринбург, ул. Софьи Ковалевской, 22.

DOI: 10.19163/MedChemRussia2021-2021-261

E-mail: e.r.gazizullina@urfu.ru

Известно, что митохондриальная дисфункция играет важную роль в патофизиологических процессах болезни Альцгеймера, следствием которой становится подавление энергоемких процессов в нейронах, повреждение свободными радикалами мембранных структур клеток, нейровоспаление, и, в конечном счете, гибель нейронов [1]. Таким образом, для эффективного лечения данного заболевания необходимы препараты сочетанного действия, проявляющие нейропротекторные и антиоксидантные свойства.

Поскольку соединения имидазольного ряда проявляют нейропротекторные свойства, а природные полифенолы - антиоксидантные, нашей исследовательской группой был выполнен синтез производных $2 \mathrm{H}$-имидазола, модифицированных фрагментами полифенолов (флороглюцин, пирогаллол, оксигидрохинон) и исследованы их антиоксидантные свойства по механизму переноса электрона и атома водорода.

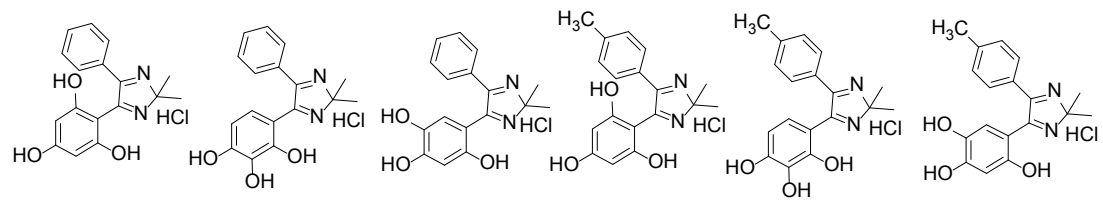

Некоторые полифенольные производные 2 Н-имидазолов, исследованные в данной работе.

Исследование антиоксидантных свойств проводили потенциометрическим методом посредством оценки антиоксидантной емкости (AOE, механизм переноса электрона) [2] и антирадикальной емкости (АРЕ, механизм переноса атома водорода) [3]. Несмотря на то, что значения AOE и АРЕ синтезированных соединений меньше исходных полифенолов, все полученные аддукты проявили антиоксидантные свойства. Наибольшее значение AOE проявили соединения с фрагментами флороглюцина и пирогаллола, а наибольшую АРЕ проявляют соединения, модифицированные флороглюцином.

Исследование проводилось при финансовой поддержке Министерства науки и высшего образования Российской Федерации (соглашение № 075-15-2020-777).

\section{Литература}

[1]. B.P.F. Rutten, H.W.M. Steinbusch, and H. Korr, Cur. Op. Clin. Nutr. 2002, 5, 645-651.

[2]. A.V. Ivanova, E.L. Gerasimova, and Kh.Z. Brainina, Crit Rev Anal Chem. 2015, 4, 311-322.

[3]. A.V. Ivanova, E.L. Gerasimova, and E.R. Gazizullina, Anal. Chim. Acta. 2019, 1046, 69 -76. 